Journal of Epidemiology and Public Health (2016), 1(1): 18-26

https://doi.org/10.26911/jepublichealth.2016.01.01.03

\title{
Path Analysis on Factors Associated with the Risk of Scabies Among Students at Darussalam Islamic Boarding School, Blokagung, Banyuwangi, Indonesia
}

\author{
Febrika Devi Nanda 1), Bhisma Murti 2), Ruben Dharmawan 3) \\ 1) Bakti Indonesia University, Banyuwangi, Indonesia \\ 2) Masters Program in Public Health, Sebelas Maret University, Surakarta \\ 3) Department of Parasitology, Faculty of Medicine, Sebelas Maret University
}

\begin{abstract}
Background: Scabies is an infectious disease that is particularly important in populations with low socioeconomic level in developing countries. Scabies is not life-threatening so usually get treatment is low. But actually the chronic and severe scabies can cause dangerous complications. This study aimed to analyze factors associated the students with scabies disease.

Subjects and Method: This was an observational analytical study with cross-sectional design. This was conducted at Darussalam Islamic Boarding School of Blokagung Banyuwangi, Indonesia in March 23 to April 30, 2016. A total of 90 samples were amounted 30 students with scabies and 60 had not scabies. Data collection was using questionnaire. Data analysis used STATA 13.

Results: Four variables associated with scabies was associated indirectly obtained between knowledge and myth was negative amounting to the value of -1.88 ( $\mathrm{p}<0.001)$ path coefficient between knowledge and healthy behaviors is positive that amounting to 1.68 with value $(\mathrm{p}=$ 0.016), the path coefficient between myth - 2:39 $(\mathrm{p}=0.038)$, the path coefficient between allowance to health behaviors positive value that is equal to $2: 00(p=0.026)$, the path coefficient between health behavior with scabies is negative in the amount - 3:43 $(\mathrm{p}<0.001)$.

Conclusion: The level of knowledge, myths, pocket money indirectly related to the incidence of scabies through healthy behaviors. It is expected to reduce disease scabies students can change the behavior of health to be good.
\end{abstract}

Keywords: scabies, level of knowledge, myths, pocket money

Correspondence:

Febrika Devi Nanda. Bakti Indonesia University, Banyuwangi.

Email: febrika_devinanda@yahoo.com

\section{LATAR BELAKANG}

Scabies is one of the most important infectious disease especially amongst those with low social economic status in developing countries. Scabies iself is not life threatening with low level of treatment. However, chronical and heavy scabies may cause dangerous complications (Golant as quoted by Ratnasari, 2012).

There are a couple of things that have a role in the height of scabies prevalance in developing countries in regards to the people's low level of health and cleanliness, difficult access to clean water and dwelling density (Gelmore 2011). The highest level of prevalence is found on places with high density population and interpersonal contact like Islamic boarding schools, orphanage, and prison (Roodsari, 2007).

Worldwide scabies prevalence is reported to be 300 million cases per year (Chosidow 2006). In industrial countries such as Germany, scabies spread out sporadically or in the shape of long term endemic (Ariza et al., 2012). Baur (2013) reported scabies prevalence in India is $20.4 \%$. While 
in Indonesia, the scabies prevalence according the Indonesian Ministry of Health based on country-wide community health centre data in 2008 was $5.6 \%-12.95 \%$. Scabies in Indonesia sits on the third place from 12 most common skin disease (Azizah 2011). Scabies incident and prevalence in Indonesia is still very high especially in the Islamic Boarding schools. This is reflected on the research done by Ma'rufi et al (2005) that the scabies prevalence in an islamic boarding school in Kabupaten Lamongan was $64.2 \%$, and this matches the result from Kuspiantoro (2005) that in Pasuruan, the prevalence was $70 \%$.

According to Islam's statistical data (2012), Islamic boarding schools (Pesantren) with the highest number of students are located in West, East, Central Java, and Banten with around $78.6 \%$ of the total number of pesantren in Indonesia. Ministry of Religion, Kabupaten Banyuwangi, Islamic Boarding Schools, Department (Kasi asrama Pontren). The data from year 2012 showed that there are 147 islamic boarding schools with 11,359 male students and 11,7258 female sudents with the total of 23,087 students. Islamic Boarding School Darussalam in Dusun Blokagung has the most students with 4,899 students consists of 1,970 male and 2,264 female students and 704 students from the village with various educational level, MI, MTS, MA, and SI with 52 students in MI, 1,679 students in MTS, 1,241 in MA and 1,927 in SI. Based on the data from clinic Asyifa in Darussalam boarding school, Blokagung from November 2014-February 2015, there are 465 students suffering from scabies on the group age $\geq 12$ years old or around the Madrasah Aliah lewel with the total of 387 students from the total students in Madrasah who suffered from scabies from November 2014 - Februari 2015.
Scabies could be transferred from direct contact or indirect contact, though direct contact is in the most cases or through indirect contact using things like bed, towels, and clothes. This disease can also be transferred through sexual intercourse between an infected person with a healthy one. This disease is very much connected to the environment and the person's cleanliness or on how many people living in a close quarter. And if the community lacks of awareness and the degree of the community's involvement in health is still low, lack of government monitoring on health, environmental problem such as clean water supply and failure in implementing health program that we often found add up the long list of environmental health problems that we already have (Siswono, 2008). Scabies infection took place when people sleep together on the same bed within the household or schools providing dormitory or lodging facilities, with health facilities that kept on being used by the public (Ma'rufi, 2005).

Scabies can be prevented by maintaining cleanliness and minimize direct or indirect contact with the patients. Reading at the above statement, the impact of scabies infection is very important to have a research done regarding factors affecting the disease.

The purpose of this research is to analyze the factors connected to the scabies case in Darussalam Blokagung Islamic Boarding School, Tegalsari Subdistrict, Banyuwangi Subdistrict.

\section{SUBJECTS AND METHOD}

The design of this research is observational analytical study with cross-sectional design. The location of this research is in Darussalam Islamic Boarding School, Blokagung, Kabupaten Banyuwangi. The research was from March 23 - April 30, 2016. The popu- 
Journal of Epidemiology and Public Health (2016), 1(1): 18-26

https://doi.org/10.26911/jepublichealth.2016.01.01.03

lation of the research was all 465 students of grade 11 of the school. Sample as many as 90 students were divided into those clinically suffering from scabies i.e. 30 study subjects and and those clinically did not suffer from scabies i.e. 60 with simple random sampling technique and data compilation technique using questionnaire. Data analysis was done with path analysis STATA.

\section{RESULT}

Specific data characteristic i.e. on the knowledge level, it was obtained that 40 study subjects (44.4\%) with good knowledge and 50 study subjects with bad knowledge (55.6\%).

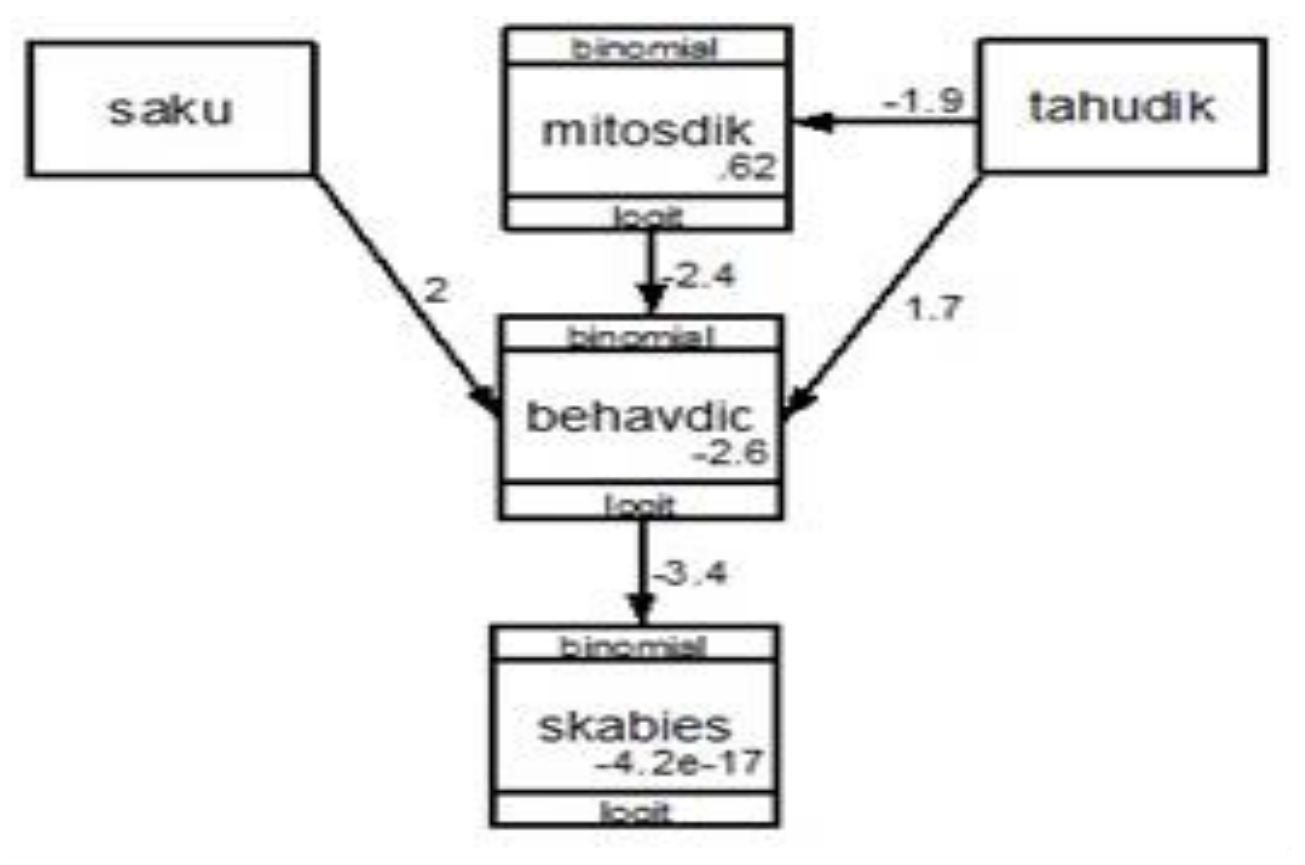

Figure 1. Path Analysis Association between Scabies dan several Predictors

Good myths with 53 study subjects (58.9\%) and wrong myths about the disease as many as 37 study subjects (41.1\%). Allowances $\geq \mathrm{Rp} 500,000$ are 51 study subjects (56.7 \%) dan allowances $\leq \mathrm{Rp}$ 500,00039 study subjects (43.3\%). Good behavious 51 study subjects $(56.7 \%)$ and some bad behaviour 39 study subjects (43.3\%). The result of the data analyis using path analysis with the help of STATA 13 is as follow:

\section{a. Model Specification}

In this model specification, the relationship among the variables surveyed is described. In this research, there are five observed variables, i.e. level of knowledge, myths, allowances, health behaviour, and scabies incident.
On table 1, the analysis result using STATA 13 software, showed that the path coefficient between knowledge and bad myth was negative, i.e. -1.88 with the value $\mathrm{p}<0.001$ is confirmed significant. But the path coefficient value between knowledge and good health behaviour was positive at 1.68 with the $\mathrm{p}=0.016$ is marked significant. Path coefficient value between myth and health behaviour is negative of $-\mathbf{2 . 3 9}$ with $\mathrm{p}=0.038$ and is confirmed significant. Path coefficient value of allowance and health behaviour is positive of 2.00 with $\mathrm{p}=0.026$ and is marked significant. Path coefficient value of health behaviour and scabies is negative of -3.43 with $\mathrm{p}<0.001$ and is marked significant. 
Table 1. Path analysis result of the relationship among knowledge level, myths, allowances, health behaviour, and scabies risk

\begin{tabular}{|c|c|c|c|c|c|c|}
\hline \multirow[b]{2}{*}{$\begin{array}{l}\text { Independent } \\
\text { Variables }\end{array}$} & & \multirow[b]{2}{*}{ Dependent Variables } & \multirow[b]{2}{*}{ b } & \multicolumn{2}{|c|}{$95 \% \mathrm{CI}$} & \multirow[b]{2}{*}{$\mathbf{p}$} \\
\hline & & & & $\begin{array}{c}\text { Lower } \\
\text { limit }\end{array}$ & $\begin{array}{l}\text { Upper } \\
\text { limit }\end{array}$ & \\
\hline Scabies & $\leftarrow$ & Good health behaviour & -3.43 & -5.49 & -1.38 & 0.001 \\
\hline \multirow[t]{3}{*}{ Good health behaviour } & $\leftarrow$ & Bad Myth & -2.39 & -4.66 & -0.13 & 0.038 \\
\hline & $\leftarrow$ & Allowances $\geq \operatorname{Rp} 500,000$ & 2.00 & 0.24 & 3.76 & 0.026 \\
\hline & $\leftarrow$ & Good knowledge & 1.68 & 0.31 & 3.06 & 0.016 \\
\hline $\begin{array}{l}\text { Bad Myths } \\
\text { N Observation }=90 \\
\text { Log likelihood }=130.14\end{array}$ & $\leftarrow$ & Good health behaviour & -1.88 & -2.82 & -.95 & $<0.001$ \\
\hline
\end{tabular}

\section{DISCUSSION}

\section{Association between scabies and myths}

The hypotheses test result showed that there is a positive relationship between the myths around students with the actual scabies incident in the boarding school, which is indirectly connected to their health behaviour. Figure 1 showed how much the influence of each relations where the indirect effect On image 1, it is showed how big the relationship. Where the relationship would be explained indirectly that between myths and health behaviour there is a negative value of -2.39 with $\mathrm{p}=0.038$ and is marked significant. So, it can be concluded that there is a negative relationship between the myth of scabies indirectly affecting through health behaviour.

The myths around the boarding school community, especially in big schools, that scabies is an "official marking" that one is a student of an islamic boarding school, and that one is ready to undergo further holistic education the school provided. A lot of clerics said, "if you already experience the itch and rashes living in the dormitory, means that you've adapted and it is easier for the knowledge to penetrate into you." Even though no one could be held liable scientifically for this statement, but based on the the authors' experience, dhawuh of these clerics were considered right. He believed that scabies suffered by the student as the early sign of God's blessing or berkah. Linguistically, the word berkah came from an Arabic word barakah stemmed from baraka, which means abundant. In tasawuf books, the blessing oftenly translated as ziyādat al khair, which means more goodness in all the things in life. A student in an islamic boarding school usually sleeps and eats together, uses the same bathroom with huge volume like a communal pool and is expected to share their clothes and towels voluntarily. On one hand, this is a very noble act of tolerance and this kind of lesson is difficult to get in normal schools. However, on the other hand, a couple of things mentioned above are exactly how the skin disease is transferred, one of which is scabies, and easily infected the students. Very close crowd makes the spreading of this disease happens very quickly. This attitude is very much expected in the school, so that whatever happens, the blessing is number one. Stories of blessed a student is in his devotion to the clerics is popular amongst them. Blessing in the knowledge is a fixed price. This blessing can be perceived as the abundance of benefit that they feel daily by feeling grateful with their living condition. The simple life of students in the school amde them believe that what they get is a good learning 
Journal of Epidemiology and Public Health (2016), 1(1): 18-26

https://doi.org/10.26911/jepublichealth.2016.01.01.03

process, including getting this disease (Syauqi, 2014).

Based on this research, it was found that the scabies incident is indirectly connected to their health behaviour. Where there is a bad myth on how scabies is a blessing that affect one's behaviour, the number of patients would rise. Therefore, this result is as per the research saying that the higher level bad myths, the higher the scabies cases.

\section{Association between knowledge and scabies}

A hypothese test result showed that there is a negative relationship between the knowledge level of the students in the school and the disease, i.e. indirectly. On image 1 , it is showed how big this indirect effect is as follow: First, the negative relationship of 1.88 between knowledge and myth; the second one has positive value of 1.68 between knowledge and health behaviour with $\mathrm{p}=0.016$ is confirmed significant. Thus, it can be concluded that the negative relationship of knowledge and scabies through health behaviour and indirectly affected by myths. Which means that the level of knowledge of these students on scabies is indirectly affecting the spreading of scabies through myths and health behaviour.

According to Notoatmodjo (2003) as quoted by Yoesrizal (2009), the knowledge is a very important domain over behaviour.

In some researches investigating the connection of knowledge like the one done by Muzakir in 2008 that investigated the factors behind spreading of scabies in several islamic boarding schools in Aceh Besar District, a significant relationship between knowledge with scabies incident was found $\mathrm{p}<0.001$ ). In this research, it was also found that between knowledge and myths there is a negative relationship of 1.88; then the second positive value of 1.68 was between knowledge and health behaviour with $\mathrm{p}=0.016$ and is marked significant. Other research about this level of knowledge took place in Semarang landfills on scavenging mothers and scabies on their toddlers clearly showed how important this knowledge and scabies $\mathrm{p}<0.001$ ). This research showed that the level of knowledge influences their daily attitude and behaviour in keeping their personal hygiene while scavengers usually have the tendency to lack in the personal hygiene. This increases the fact that scabies is very much related to personal hygiene (Masruroh, 2014).

The research done by Ummul in 2011 that investigated on the factors connected to scabies incident in Darul Huffadh Islamic Boarding School under Kajuara community health center, Kabupaten Bone, expained that the factors affecting scabies are among others: knowledge level $\mathrm{p}<$ 0.001 , personal hygiene practice $\mathrm{p}<0.001$, and attitude $\mathrm{p}<0.001$, this research explains that one's level of knowledge is very important to help forming one's attitude for early detection to prevention of the disease (Setyowati, 2014).

The result from Darusalam Islamic Boarding School, Blokagung also shows that knowledge about this disease is also a dominant factor in shaping up good health behaviour. The lack of knowledge will also affect how myths influence one due to lack of direct sensing or using tools or even human reasoning thus creating negative relationship between myths and behaviour related to the disease. It can be concuded that the result of this research is in accordance to above researches that stated there is negative relationship between knowledge and scabies through behaviour and indirectly affected by myths. 


\section{Association between Scabies and allowances}

The hypothesis test result showed there is a negative relationship between allowances and scabies in the school, which is indirectly. Image 1 showed how big the influence is where the indirect relationship would be explained that there is a positive relationship between allowances and health behaviour with the value 2 with $\mathrm{p}=0.026$ and is marked significant. Thus, it can be concluded that there is a negative relationship between allowances and scabies with indirectly affecting through behaviour. Which means, the bigger the allowances given by the parents, thus it would indirectly affecting the scabies incident through behaviour.

Social economy status is one of the aspects in shaping one's lifestyle. Good social economy will support a child's growth because with enough economy, one could provide for all the needs primary and secondary (Soetjiningsih, 2004).

To be able to keep good personal hygiene, good facilities and infrastructure like bathroom, bath equipment, and other bath necesities (such as soap, toothbrush, shampoo, etc) are needed. This cost money, or in other words, individual financial source very much affected their ability to maintain personal hygiene. The factors affecting the transfer of this disease are low social economy status, bad personal hygiene, unclean living environment, bad habit that does not support health, and population density or living areas. The most dominant factor is poverty and bad personal hygiene which are very common in developing countries and this group of people are the one mainly affected by the disease (Carruthers, 1978; Kabulrachman, 1992).

From the result of research, it as found that there is an indirect relationship among the allowances, scabies and health behaviour. Whereas students with Rp 500,000 allowances will lower the risk of getting this disease thus can be concluded that this research is in accordance with the previous researches.

\section{Connection between health beha- viour and scabies}

The hypotheses test result showed that there is a negative relationship between the health behaviour and scabies infection to the students of Darussalam Islamic Boarding School, Blokagung. Figure 1 showed how big the relationship where it was gathered that there was a path coeffiecient value of -3.43 with $\mathrm{p}<0.001$ is marked significant. Thus can be concluded there is a negative direct relationship between one's behaviour to scabies infection.

The health behaviour is one way to avoid the infection. The attitude towards health is very much affecting the number of scabies in public living space like in an orphanage, boarding schools, as well as people's settlement. Islamic boarding school is one of the place where this disease survived because they usually shared their belongings together such as towels, bed sheets, and clothes (Notoatmodjo, 2010).

The components from healthy clean living behaviour that would help preventing the spreading of this disease are baths twice a day; in the morning and afternoon; use soap when bathing, tooth brushing, clean hair washing, hand washing with soap, toes and nails clipping as well as using clean clothes, and avoid exchange clothes with the others.

Actively keeping and maintaining the cleanliness in the dormitory and diligently clean the beds, wash the sleeping equipment at least once a week, eat and drink nutritious stuff and avoid buying food and drink randomly which does not have any guarantee on its hygiene. If the students could do the above components, they could 
Journal of Epidemiology and Public Health (2016), 1(1): 18-26

https://doi.org/10.26911/jepublichealth.2016.01.01.03

avoid themselves from this disease because the only way to avoid getting this disease is by maintaining personal hygiene.

The research showed that there is an indirect connection between clean living behaviour and scabies on the female students. This is strengthen by the research done by Mariana (2010) that showed that there is a connection between personal hygiene and scabies suffered by the students, from 97 respondents, 77 (79.38) suffered from scabies while 20 (20.62) does not. This is due to bad personal hygiene amongst the students (59.8\%).

Based on the above statement, this research therefore showed that indeed there is a connection between behaviour and scabies. Thus, this research is in accordance the the mentioned statement.

Based on the explanation above, it can concluded that the level of knowledge, myths, and allowances indirectly affecting scabies through clean living. The path coefficient value between knowledge and myths are negatif of -1.88 with $\mathrm{p}<0.001$, the path coefficient value between knowledge and clean living behaviour is positive 1.68 with $\mathrm{p}=0.016$, while the value between myths and clean living is negative -2.39 with $\mathrm{p}=0.038$. The value between allowances and clean living behaviour is positive 2.00 with $\mathrm{p}=0.026$, while the value between clean living behaviour and scabies is negative -3.43 with $\mathrm{p}<0.001$.

\section{REFFERENCE}

Anisa F (2013). Hubungan Hygiene Perorangan dan Sanitasi Lingkungan terhadap Kejadian Scabies pada Santri di Pondok Pesantren Rudhotul. Skripsi, Fakultas Kesehatan.

Andayani LS. (2005). Perilaku Santri dalam Upaya Pencegahan Penyakit Scabies di Pondok Pesantren Ulumul Qur'an
Stabat. Info Kesehatan Masyarakat. 9(3).

Ariza L. (2012). Investigation of a Scabies Outbreak in Kindergarten in Constance Germany. Europe Journal Clin Microbial Infect Dis. (10): 1007-1096.

Audhah. (2012). Faktor Risiko Scabies pada Siswa Pondok Pesantren. Kajian di Pondok Pesantren Darul Hijrah, Kelurahan Cindai Alus, Kecamatan Martapura, Kabupaten Banjar, Provinsi Kalimantan Selatan. 4(1): 14-22.

Azizah I (2011). Hubungan Tingkat Pengetahuan Ibu Pemulung tentang Personal Hygiene dengan Kejadian Scabies pada Balita di Tempat Pembuangan Akhir Kota Semarang. Dinamika Kebidanan. 1: 1-5.

Baur B (2013). The Pattern of Dermatological Disorders among Patients Attending the Skin O.P.D of A Tertiary Care Hospital in Kolkata, India. Journal of Dental and Medical Sciences. 3: 1-6.

Chowsidow O (2006). Scabies. The New England Journal of Medicine. 35:1-16.

Departemen Kesehatan Republik Indonesia. (2007). Pedoman Penyelenggaraan dan Pembinaan Pos Kesehatan Pesantren.

Dhofier (1994). Tradisi Pesantren: Studi tentang Pandangan Hidup Kyai: LP3ES.

Dinas Kesehatan Lumajang. (2013). PHBS 5 tatanan dan pondok pesantren. Di akses dari http://dinkeslumajang.or. id/phbs-5-tatanan-dan-pondokpesantren/.

Djuanda A (2006). Ilmu Penyakit Kulit dan Kelamin, Jakarta: Fakultas Kedokteran Universitas Indonesia.

Friedman (2004). Keperawatan Keluarga. Jakarta:EGC

Gilmore SJ (2011). Control Strategies for Endemic Childhood Scabies. 
Golant AK, Levitt JO. (2012). Scabies: a Review of Diagnosis and Management Based on Mite Biology. Pediatr Rev Jan. 33(1):e1-e12. doi: 10.

Handajani (2007). Hubungan Antara Praktik Kebersihan Diri dengan Kejadian Scabies di Pondok Pesantren Nihayatul Amal Waled Kabupaten Cirebon. Diakses dari. http://fkm. undip. ac.id/data/index.php?action $=4 \&$ idx $=$ 3264 .

Handoko R (2007). Ilmu Penyakit Kulit dan Kelamin. Edisi Kelima. Jakarta: Fakultas Kedokteran Universitas Indonesia. 122-125.

Handoko R (2009). Scabies. Dalam: Ilmu Penyakit Kulit dan Kelamin. Fakultas Kedokteran Universitas Indonesia, Jakarta. 122-125.

Harahap (2000). Ilmu Penyakit Kulit. Jakarta : Hipokrates.

Heukelbach J (2005). Epidemiology and Morbidity of Scabies and Pediculosis Capitis in Resource-Poor Communities in Brazil. British Journal of Dermatology. 153: 150-156.

Kabulrachman (1992). Pengaruh Lingkungan dan Pencemaran Terhadap Penyakit Kulit. Majalah Kedokteran Indonesia. 42 (5): $273-277$.

Kementrian Agama (2012). Analisis dan Interpretasi Data pada Pondok Pesantren, Madrasah Diniyah (Madin), Taman Pendidikan Qur'an (TPQ) Tahun Pelajaran 2011-2012. 68-106. Available at: http://pendis.kemenag. go.id/ file/dokumen/pontrenanalisis.pdf.

Kline K (2013). Neglected Tropical Diseases of Oceania: Review of Their Prevalence, Distribution, and Opportunities for Control. Plos Neglected Tropical Diseases. 7: 17-55.

Kartono (2006). Perilaku Manusia. ISBN. Jakarta.
Kurniawati D (2004). Hubungan antara Kebersihan Pribadi dan Kontak Perseorangan dengan Kejadian Scabies pada Anak SD yang Berobat di Puskesmas Gemuh 1 Kecamatan Gemuh, Kabupaten Kendal. Skripsi. Universitas Muhammadiyah.

Kuspriyanto (2013). Pengaruh Sanitasi Lingkungan dan Perilaku Sehat Santri terhadap Kejadian Scabies di Pondok Pesantren Kabupaten Pasuruan Jawa Timur. Jurnal Ilmiah UNS. 11:21.

Linda A (2010). Praktik Perilaku Hidup Bersih dan Sehat pada Peserta Pendidikan Anak Usia Dini. Jakarta Utara: Universitas Muhammadiyah.

Mariana (2010). Hubungan Perilaku Personal Hygiene Dengan Kejadian Scabies pada Santri Aliyah Pondok Pesantren Albadriah Sundak Desa Rarang Kecamatan Terara Lombok Timur, NTB. STIKES Aisyiyah. Yogyakarta

Masruroh (2014). Hubungan Perilaku Hidup Bersih dan Sehat (PHBS) dengan Kejadian Scabies pada Santriwati Pon dok Pesantren Assalafiyyah Mlangi Nogotirto Sleman. Naskah Publikasi STIKES Aisysah Yogyakarta.

Ma'rufi I (2005). Faktor Sanitasi Lingkungan yang Berperan terhadap Prevalensi Penyakit Scabies Studi pada Santri di Pondok Pesantren Kabupaten Lamongan. Jurnal Kesehatan Lingkungan. 2:11 - 18 .

Murti B (2013). Desain dan Ukuran Sampel Untuk Penelitian Kuantitatif dan Kualitatif di Bidang Kesehatan. Yogyakarta: Gajah Mada University Pres.

Noor (2008). Epidemiologi Penyakit Menular. Jakarta: Rineka Cipta.

Onayem O (2005). Prevalence of Different Skin Conditions in an Outpatients' Setting in North-Western Nigeria. International Journal of Dermatology. 44: 7-11. 
Journal of Epidemiology and Public Health (2016), 1(1): 18-26

https://doi.org/10.26911/jepublichealth.2016.01.01.03

Rahmawati R (2010). Hubungan antara Faktor Pengetahuan dan Perilaku dengan Kejadian Scabies di Pondok Pesantren Al-Muayyad Surakarta. Skripsi. Fakultas Ilmu Kesehatan Masyarakat Universitas Muhammadiyah Surakarta.

Rahim A (2006). Faktor yang Berubungan dengan Terjadinya Penyakit Scabies pada Anak ditempat Pengungsian Waipotih Kabupaten Buru, Provinsi Maluku.Universitas Airlangga. Thesis. Surabaya.

Ratnasari (2014). Prevalensi Scabies dan Faktor-Faktor yang Berhubungan di Pesantren X, Jakarta Timur. Jurnal Fakultas Kedokteran Universitas Indonesia. 2(1).

Rohmawati R (2010). Hubungan antara Faktor Pengetahuan dan Perilaku dengan Kejadian Scabies pada Santri di Pondok Pesantren Al-Muayyad Surakarta. Skripsi. Universitas $\mathrm{Mu}-$ hammadiyah Surakarta.

Setyowati (2014). Hubungan Pengetahuan Santriwati tentang Penyakit Scabies dengan Perilaku Pencegahan Penyakit
Scabies di Pondok Pesantren Gaster. 11 (2).

Siswono (2008). Pedoman Umum Program Pemberantasan Penyakit Lingkungan. Departemen Kesehatan RI. Jakarta.

Soetjiningsih. (2004). Tumbuh Kembang Anak. Jakarta: EGC.

Sungkar S (1997). Scabies. Majalah Kedokteran Indonesia 47 (01): 33-42.

Sungkar (1992). Cara Pemeriksaan Kerokan Kulit Untuk Menegakkan Diagnosis Scabies, Medika. 7: 60 - 62.

Ummul H (2011). Faktor -Faktor yang Berhubungan dengan Kejadian Scabies di Pondok Pesantren Darul Huffadh di Wilayah Kerja Puskesmas Kajuara Kabupaten Bone. Jurnal Media Kedokteran. 2(4): 1-6.

Wijayanti Y (2006). Hubungan Sanitasi Lingkungan dan Higiene Perorangan dengan Penyakit Scabies di Desa Genting Kecamatan Jambu, Kabupaten Semarang (Skripi). Semarang.

Zayyid M (2010). Prevalence of Scabies and Head Lice among Children in a Welfare Home in Pulau Pinang, Malaysia. Tropical Biomedicine. 27: 44. 